\title{
SPIRITUALISASI LINGKUNGAN MATERIEL DAN MORAL KENABIAN DALAM MODERNITAS
}

\author{
Abdul Munir Mulkhan
}

Pendahuluan

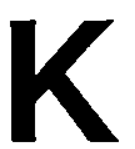

emajuan masyarakat yang semakin modern dan makmur,ternyata tidak mampu mengubur potensi tindak kejahatan dan kekerasan sosial yang justru meningkat. Kejahatan, sadisme dan kekerasan sosial tampaknya berada di luar kemodernan, ketradisionalan dan keterbelakangan, sehingga kebiadaban dan kekejaman manusia bisa terjadi dalam masyarakat berperadaban tinggi dengan kemakmuran ekonomi. Hal itu menunjukkan bahwa kejahatan ekonomi, politik dan kejahatan lainnya terjadi menyilang melintas sepanjang kutub-kutub budaya dan peradaban. Jika secara teoritis moral adalah elemen dașar, maraknya kejahatan menunjukkan kegagalan peradaban modern mengemban amanat sebagai tempat penyemaian moralitas.

Sayangnya, orang modern tidak memiliki kamus lengkap mengenai dunia moral yang metafisis yang terlanjur diberi cap non-rasional, tak dikenal dan tidak penting. Moralitas hanya dianggap penting sepanjang membantu kemajuan pisik materiel, sehingga pembangunan moral diletakkan dalam kerangka ekonomi dan politik. Akibatnya, terjadilah proses materialisasi moralitas yang memang mempermudah perencanaan dan evaluasi hasil materiel yang dicapai.
Berita mengenai tindak kekerasan dan kejahatan masih terus memenuhi lembaran koran, sehingga persoalannya bukan bagaimana itu terjadi tetapi masih adakah jalan menghentikannya. Orang pun bertanya bagaimana hidup tanpa khawatir tanahnya terserobot, pergi bekerja tanpa bayangan maut bagi dirinya dan keluarga yang ditinggalkannya di rumah. Hal ini menunjukkan bahwa dalam dunia beradab tetap berlaku mitos yang perkasa, menang dan manusia, serigala bagi manusia lainnya. Bangunan gedung bertingkat yang menjejali kota besar dengan manusia yang semakin padat tak ubah hutan belantara di pedalaman Kalimantan dan Irian Jaya, karena manusia kota tetap diburu ketakutan bukan terhadap hewan buas tapi kebuasan dan kebiadaban manusia yang hidup modern.

.Dalam hal itu, Nabi-ñabi diutus dalam suatu kurun peradaban untuk mencerahi moral sebagai basis kehidupan. Baiat pertama atas. Muhammad Sang Nabi agar manusia menyadari jati kemanusiannya seperti isi pesan lima ayat pertama Al Quran yaitu kritik diri sehingga menyadari proses kejadiannya. Karena itu moral kenabian patut direnungkan agar mencerahi pikiran dan tindakan.

Moral kenabian adalah cara pandang jauh ke depan al akhirat menembus batas wilayah geografis dan zaman jauh ke ujung paling dalam dan paling ekstrim. Sosok 
Muhammad adalah sosok yang tindakan dan pikirannya jauh melampuai kemampuan manusia biasa sehingga setelah sekian lama orang baru mengerti maksud tindakan atau perkatannya. Untuk itu perlu pembangkitan kembali moral agar manusia menyadari sepenuhnya hakikat hidup dan dunianya, hakikat diri, keluarga dan tetangganya, hakikat tuan dan pekerja serta hakikat pemimpin dan rakyat yang harus dipimpinnya.

\section{Dimensl Etik Lingkungan Alam ${ }^{1}$}

Jika dikatakan bahwa prinsip paling dasar dari manusia dan alam pada akhirnya bersifat rasional fisis, maka tata lingkungan hanya akan merupakan sekedar kaidah formal bagaimana manusia bertindak terhadap diri dan alam.Sebaliknya, apabila prinsip utama akhirnya non-rasional atau rasional metafisis, etika lingkungan bukan hanya kaidah formal melainkan kesadaran mengenai hubungan manusia dengan yang metafisis.

Sesuai pandangan terakhir, sejarah dan hirarhi hal ada merupakan kajian penting etika lingkungan. Schumacher (Keluar, 1980) menyatakan bahwa ada hubungan hirrakhis seluruh alam dan manusia menempati posisi puncak. Sikap penolakan terhadap fungsi asli alam bagi manusia berarti ketidaksesuaian dengan akibat kehancuran manusia dan alam itu sendiri. Seluruhnya menunjukkan hubungan etika dengan berbagai kepentingan manusia termasuk pelestarian lingkungan alam fisis atau metafisis. Karena itu, etika disebut filsafat praktis yang berhubungan dengan tindakan empiris.

Selama ini, pembangunan merupakan operasi teori modernisasi yang merujuk pada pandangan filosofis yang positivistis yang menyatakan bahwa alam fisis adalah prinsip dasar seluruh keberadaan termasuk yang bersifat ruhaniah. Pandangan ini cepat memperoleh dukungan karena mudah dilihat dan diukur terutama dalam mengevaluasi kegagalan atau keberhasilan pembangunan. Namun sejak tahun 70-an modernisasi justru dipandang telah gagal memahami realitas sehingga kebijakan pembangunan menyebabkan kerusakan lingkungan, dehumanisasi dan keterasingan manusia dari diri dan alam sekitarnya (Hardiman, 1990 \& 1993).

Melalui sikap kritis akan diperoleh pemahaman dan kesadaran hakikat dan maksud suatu perundangan sehingga seseorang bertindak otonom mempertanggungjawabkan setiap tindakannya (Magnis, 1979). Karena itu, dimensi etik dari lingkungan alam akan berarti kesadaran mengenai hakikat manusia dan alam. Manusia memang memiliki banyak peluang untuk bertindak tetapi justru bagaimana manusia mampu dan bersedia menahan diri. Bukan karena tuntutan hukum, tapi kesadaran mengenai akibat tindakan itu yang diderita orang lain, walaupun mereka tidak berani menyatakannya.

Kecenderungan "kerakusan" manusia atas sumber daya alam yang sering atas nama pembangunan bersumber cara pandang tidak berkembangnya bumi, alam serta energi (Schumacher, Kecil, 1985). Konsepsi yang menggerakkan modernisasi dan teknologisasi, juga memunculkan sikap yang tampak berlawanan. Sebagian merekomendasi pengembangan wawasan etik dan yang lain mendorong perampasan penguasaan sumber daya alam sekeras dan sebanyak mungkin.

Pandangan demikian antara lain bersumber dari spekulasi filosofis Nietsczhe mengenai "kematian Tuhan" sehingga Tuhan berhenti mencipta. Penelitian ilmiah yang sampai kini tak dapat menghindar dari manipulasi teoritis

1) Bahasan ini pernah disampaikan dalam Seminar Etika lingkungan Dalam islam oleh KPS Lingkungan Hidup P3MIAIN Sunan Kalijaga, 12/8/95 
memang menunjukkan bukti pendukung, sehingga modernisasi dan teknologisasi cendenung menjadi ideologi. Bumi; alam dan energi dipandang sebagai realitas statis tidak bertambah dan berkembang, sehingga eksploitasi besar-besaran berakibat pengurangan simpanan energi yang mengindikasikan hari kiamat. Sementara terperangkapnya energi dalam teknologi dari ikatan aslinya menyebabkan pelipatan panas, sehingga alam raya meleleh, kutub utara dan selatan mencair, banjir terjadi di seluruh bumi yang berakhir dengan kiamat.

Fisika modern mulai membantah spekulasi di atas dengan alasan masih berlangsungnya ledakan-ledakan besar yang memungkinkan munculnya planet baru yang berpengaruh terhadap struktur bumi dan alam semesta. Spekulasi ilmiah yang masih diperdebatkan tetap memungkinan percepatan kiamat seperti kerusakan ozon dan lingkungan yang hebat. Akibatnya perampasan tanah mereka yang kuat atas yang lemah terus berlangsung karena ketakutan segera datangnya kiamat.

Persoalannya, bagaimana memenuhi kebutuhan hidup tanpa teknologi ketika manusia terperangkap teknologi. Sayangnya, manusia terlanjur percaya bahwa tanpa teknologi hidup manusia seolah tak bermakna bahkan ragu tak dapat bertahan hidup. Masalah inj akhirnya tergantung cara pandang manusia terhadap alam dan teknologi atau ilmu. Dalam pandangan modern, tidak ada instansi yang berhak memerintah atau melarang manusia memenuhi kehendaknya kecuali dirinya sendiri. Pertanyaan, mengapa tidak bersedia mengendalikan sebagian keinginannya daripada menggusur orang lain, dipandang tidak ekonomis. Demikian pula pertanyaan mengapa manusia tidak menahan diri mengkonsumsi energi yang berlebihan.

Pembangunan yang dilihat dari perspektif ekonomis menyebabkan kehidupan sosial-budaya diletakkan dalam kemaknaan ekonomis yang subordinatif. Tanpa perspektif metafisis dan teologis tak lama lagi industrialisasi yang membutuhkan lahan yang luas di kawasan pinggiran kota dan pedesaan akan mendorong penggusuran dan mempertinggi tingkat keresahan sosial. Kebutuhan sarana transportasi akan membelah desa dengan jalan-jalan raksasa dimana banyak warga pedesaan tidak dapat mengambil banyak manfaat kecuali perubahan struktur budaya dan kepribadian mereka. Pohon-pohon hijau pun berganti bangunan bertingkat. Sumber air berkurang dan metabolisme alam menjadi terganggu. Persoalannya bukan sekedar persoalan politik dan ekonomi melainkan persoalan etis; tidak bahagiakah manusia yang hanya berjalan kaki dan lambat- mencapai titik tertentu alam semesta?

Tak hanya alam dilepaskan dari nilai metafisis ruhaniah, manusia pun dianggap sebagai obyek materiel yang dikelola dengan paradigma serupa. Eksploitasi sumber daya alam mencapai puncak tertinggi atas nama kemanusiaan, manusia pun direkayasa guna mendukung cita-cita dan idealitas materialisme di.bawah daliidalil ekonomis. Bahkan penciptaan mesin perang dan senjata nuklir pun tak lepas dari kepentingan ekonomis (Zen, 1981).

Peradaban modern-industrial, tak cukup sabar mengkaji masalah moralitas yang abstrak dan sulit dievaluasi, kecuali diletakkan dalam format fisik-materiel untuk mempermudah perencanaan dan evaluasi. Sikap ini adalah akibat kuantivikasi dan materialisasi waktu yang diartikan sebagai sekuen perjalanan bumi mengitari matahari dalam satuan detik, menit, jam dan hari serta tahun. Sementara ruang diartikan sebagai jarak tisis dalam satuan meter. Seluruh benda dalam ruang hanya berarti jika memiliki hubungan fungsional dengan yang materiel tanpa dimensi ruhaniah kecuali terletak dalam ruang-waktu fisis. Hidup manusia diberi makna sebagai gerak ruang-waktu 
kuantitatif yang terbatas sebagai alat pencapaian target ekonomi materialistis.

Sains dan teknologi sebagai sumber daya modernitas dan industrialisasi hanya melihat manusia dan alam dari satu sudut pandang secara reduktif dan tidak utuh (Poincare dalam Zen, 1981'). Seperti pernyataan Bronowski (dalam Zen, 1981) bahwa dalam ilmu,jantung kehilangan satu denyutan. Daya kritis demikian hanya mungkin jika manusia memiliki wawasan etis sehingga memiliki peluang melihat alam dan dirinya dari sisi lain yang tidak sekedar ilmiah. Moralitas dimanipulasi dan direkayasa sehingga dapat mendukung pencapaian tujuan materiel. .Kepribadian manusia dievaluasi sepanjang aturan formal lahiriah, sehingga kebaikan atau keburukan adalah kesesuaian perilaku empirik dengan kaidah formal hukum dan perundangan. Di luar ukuran yang sudah dibakukan tersebut diartikan sebagai ketidakbaikan atau keburukan.

Akibatnya sekuen rasa kehidupan yang memang sulit ditangkap oléh ukuran formal materiel - menjadi terabaikan dan tidak penting. Kebahagiaan dan penderitaan kehidupan manusia dibakukan dalam ukuran formal materiel. Dimensi ruhaniah dan kejiwaan diartikan sebagai terpenuhi atau tidaknya kebutuhan. materiel. Kehormatan dan harga diri diletakkan dalam prosedur formal dan prestasi fisikalnya. Tradisi ini memerlukan refleksi mendalam mengenai hari depan manusia dan mempertanyakan kembali nilai moral dan etis kehidupan. Seorang ahli ekonomi Jerman Schumacher (1985) kemudian mengumandangkan rekomendasi etis di bawah semboyan small is beautiful. Sejauh ini rekomandasi demikian tak banyak di dengar, dan manusia pun terus memepuhi kerakusannya atas sumber daya alam dan mematerialisasi manusia.

Selain rekomendasi etis. di atas, muncul kritik tajam mengenai kerusakan lingkungan beserta kritik dehumanisasi dan degradasi kemanusiaan. Walaupun demikian, iptek yang seolah terlepas dari kehidupan manusia dan campur tangannya, terus memaksa manusia menjalani hidup di bawah bayangan keperkasaannya. Soolah tanpa memperdulikan kritik etik, eksploitasi sumber daya alam terus berlangsung tanpa henti.

Di sisi lain, penguasaan sekelompok orang atas tanah mulai mempengaruhi hubungan sosialnya. Tak peduli apakah hal itu akan mengakibatkan penderitaan banyak orang yang tak menguasai sumber daya politik dan ekonomi, atas nama kemanusiaan dan pembangunan terus dilegalisasi. Kemajuan pembangunan seolah identik dengan perluasan penderitaan dan keterampasan hak banyak orang dan eksploitasi besarbesaran sumber daya alam.

Muncul pertanyaan serius, apakah kesejahteraan hidup memang memerlukan jalan tol, pabrik-pabrik dan pesawat serta barang elektronik yang untuk keperluan itu lingkungan hidup harus rusak dan banyak manusia harus menderita dan tersingkir dari bumi tempat tinggalnya. Walaupun kebutuhan ruang mulai diminimalisasi teknologi chip, namun tak disadari bahwa untuk memelihara barang elektronik dalam mencukupi kebutuhan manusia juga memerlukan ruang yang lebih luas yang hanya bisa dipenuhi dengan menggusur banyak orang lain. Muncul pertanyaan apakah efisien jika untuk memproduksị barang yang hanya dapat dinikmati serta memenuhi kebutuhan sedikit orang harus membuat banyak orang menderita. Demikịan pula pertanyaan apakah perubahan paradaban manusia hanya berkaitan dengan pertambahan jumlah penduduk dalam kelipatan deret ukur atau karena arah pemikiran manusia; apakah arah pemikiran manusia berhubungan dengan pertambahan jumlah manusia atau karena nilai intrinsik perkembangan alam itu sendiri. Perlu dikaji apakah alam itu tetap ataukah mengalami perkembangan. 
Jawaban pertanyaan itu menjadi. dasar pengembangan strategi lingkungan yang hanya mungkin dalam wawasan ètis kehidupan manusia. Seperti pernyataan Sains-Exupery (Mathilde Niel, dalam Zen, 1981) “jika rasa hormat kepada manusia ditanamkan dalam hati manusia, (grs bawah/ pen) barulah manusia akan berhasil membangun sistem politik, sistem sosial, dan ekonomi yang menghormati dasar-dasar kemanusiaan itu". Barbara Ward \& Rene Dubos (1974) menulis "Pada tingkat kepentingan sendiri yang, paling konkrit, kesadaran (grs/ pen) bahwa udara, tanah, dan air di seluruh planit ini ada di dalam satu sistim yang sepewnuhnya bersambungan dan. saling-tergantung itulah yang telah mempermudah usaha untuk mencegah puncak' kegilaan persenjataan nuklir". Sayangnya, Iptek hanya sampai pada kebenaran sampling, sehingga untuk mencapai kesadaran etik diperlukan pendekatan kritik.

\section{Moral Kenablan sebagal Paradigma Pembangunan² \\ Beberapa persoalan yang selalu} tersisa dari proyek pembangunan dan modernisme ialah; kerusakan lingkungan, ketidakadilan, kemiskinan dan dehumanisasi, bahkan semakin buruk dalam peradaban global. Pada saat demikian, ramalan mengenai kebangkitan agama yang maksudnya belum jelas kecuali dalam paradigma modernisme, menimbulkan antuiasme agamawan. Antusiasme ini, sebaliknya justru dicurigai potensial memicu konflik yang lebih keras dan global (Huntington, 1995, hlm 381406).

Menghadapi persoalan dunia global yang menyisakan masalah mikro kemanusiaan tersebut di atas, pemikiran Islam setidaknya harus dapat berdialog dengan modernisme dan kerangka budaya yang diciptakannya. Sekurangnya, dapat menawarkan pemecahan persoalan modern, sehingga beriman sekaligus modern atau sebaliknya.
Dalam bahasa ekonomi, pemikiran Islam menjadi paradigma model harapan rasional (rational expectetion) mengenai masa depan yang lebih berorientasi pada kemanusiaan (meminjam konsep Robert Lucas; Kompas, 17/10/95 him 13). Risiko sosial ketidakadilan, ketimpangan dan kemiskinan yang meluas merupakan dasar pengembangan kesadaran, sehingga memotivasi pelaku ekonomi dan politik. Juga model public choice (PC) perlu menjadi landasan pengembangan etika bisnis sebagai komitmen pelaku ekonomi bagi pemberdayaan rakyat (Kompas, 23$26 / 10 / 1995)$, dan etika politik pemihakan mikro ekonomi-politik (Berger, 1982). Keagamaan dalam pesan kenabian berarti bebas dari struktur modernisme tanpa menghindar atau menolak, tetapi sebagai sintesis non-hegelian.

\section{Perangkap Keagamaan dan Modernisme ${ }^{3}$}

Modernisme bersumber rèvolusi ekonomi, politik dan filosofis renaisance dan aufklarung abad ke 16 lahir dari akar ideologis; (i) bebas dari agama (gereja) dan (ii) fisika ditempatkan sebagai paradigma humaniora (kemanusiaan). Di satu sisi modernitas merupakan kritik kegagalan peran agama (Hadiwijono, Jid $1 \& 2,1980)$, namun bertanggungjawab atas sejumlah ketidakadilan. Kaum intelektual, ternyata kembali gagal

2) Naskah ini semula berjudul "Moral Kenabian; Paradigma Manusia Dalam Pembangunan". Naskahtersebut pemah disampaikan dalam Seminar Nasional "Pembangunan dalam Perspektif Martabat Manusia", dengan sub-tema Pembangunan Bermartabatmanusia; Sebuah Telaah Keagamaan", UM Surakarta, 29-30 Nopember 1995

3) Kajian kritis modernisme diambil dari makalah yang akan disampaikan dalamSeminar Nasional "Pembangunan dalam Perspektif Martabat manusia", dengan sub-tema "Pembangunan Bermartabat manusia;Sebuah Telaah Keagamaan" UM Surakarta, 29-30 Nopember 1995 di bawah judul - Moral Kenabian; Paradigma Manusia Dalam Pembangunan". 
membela manusia dari penindasan atas nama agama dan Iptek (Schumacher, Kecil, 1985).

Dalam perkembangan mutakhir, teori hukum fisik mulai menempatkan ketidakterukuran tungga ${ }^{4}$ dalam menjelaskan sejarah alam semesta. Terdapat kesadaran baru mengenai jalinan hubungan realitas metafisis dengan fenona alam kehidupan. Pada saat yang sama, paradigma. kemanusiaan masih. terkungkung fisika klasik seperti kecenderungan keagaman legal formalistis. Teknologi, menjadi legitimasi "kolonisasi" yang memandang diri lebih beradab (Berger, 1982), sehingga hampir mustahil kesejahteraan dunia dinikmati semua kawasan (Schumacher, Kecil, 1985). Hanya ada satu pilihan bagi kawasan berkembang yaitu berjuang sendiri penuh kepercayaan bagikesejahteraannya (Haq; 1983; Berger, 1982).

Ketidakadilan demi keunggulan yang berkualitas menunjukkan cacat bawaan logika modern, yang membuat manusia bagaikan ramsès. Karena itù, keagamaan modern harus merupakan konsep kemanusiaan sebagai sintesis nonhistoris- realitas materiel dan' spiritual metafisis ${ }^{5} .$. Keagamaan merupakan pergumulan sejarah manusia menafsir doktrin wahyus dengan dunia obyektif yang historis (bin' Nabi, Dunia Baru; 1995; Rahman, litihad, 1984).

Mega-budaya abad informasi, dan pasar tunggal perdagangan bebas (Naisbitt, 1994; \& Aburdene, 1990), menyisakan ketidakadilan dan kemiskinan. Globalisasi ruang hidup tetap belum mengatasi dehumanisasi. Perhatian pendekatan yang lebih berorientasi makro perlu dikoreksi dengan realitas mikro mengenai kemiskinan. Memasuki abad'21, setiap orang memiliki akses terhadap informasi global dari "seribu" pintu dan "seribu" penjuru berhubungan timbal balik dengan jutaan orang. Satu dari 100 orang, dapat mengambil keputusan sendiri dengan "seribu" alternatif yang disediakan mesin komputer dalam sistem internet tanpa konsultan. Manusia berada dalam peradaban publik, sekaligus tidak mengenal orang lain secara pribadi (Naisbitt, Paradox, 1994).

Persoalan peradaban modern masih dalam tesis Malthus dan "kiamat" Club of Roma dalam format dan kontroversi berbeda (Kennedy, 1995). Sementara optimisme John Naisbitt dan isterinya (1990, hlm 15-17), mengenai pertumbuhan ekonomi negara industri 100 kali wilayah miskin, mengabaikan resiko ketimpangan distribusi pangan dan energi serta kemiskinan lebih 1 miliar manusia. Situasi serupa juga dihadapi dalam nasionalitas Indonèsia.

Situasi di atas membuat sistem dan struktúr modernitas dengan mulus melestarikan konflik dan melahirkan kesenjangan struktural, dalam basis ketidakadilan.Hingga akhir abad ke 21, laju pertumbuhan penduduk kawasan terbelakang tetap lebih tinggi, sementara

4) Lihat Singularitas Ketaterhinggaan dalam Stephen Hawking Blach Hotels And Baby Universes; Lubang hitam Dan Jagat Bayi dan Esei-esei Lain, Gramedia, Jakarta, 1995; juga dalam Riwayat Sang Kala; Dari Detuman Besar hingga Lubang Hitam, Pustaka Grafiti Utama, 1994, Jakarta.

5) Murtadha Mutahari menyebutkan sistematis tersebut dengan tiga tingkatkesdara;iman, kemausiàan dan tanggung jawab kemasyarakatan (Masyarakat dan Sejarah; Kritik Islam atas Marxisme dan Teori lainnya, 1986, Mizan, Bandung hlm 194195). Izutsu merumuskan sebagai refleksi hubungan amal shaleh dengan keyakinan atas sifat-sifat Tuhan realitas perilaku obyektif (Konsep-konsep Etika Religius dalam Qur'an, 1993, Tiara Wacana Yogyakarta. Ziauddin Sardar menyatakan sebagai kemajuan metafisis kesadaran diri (usaha "keselamatan pribadi") dalam refleksi his sosial, sehinggakeselamatan diri adalah keselamatan orang lain dan masyarakat (Sains, Teknologi dan Pemabangunan di Dunia Islam, 1989, Pustaka, Bandung, hlm. 36-39). Ilyas Ba-Yunus \& Farid Ahmad menyebut sebagai jalan-tengah (Sosiologi Islam \& Masyarakat Komtemporer, 1993, Mizan, Bandung hilm 60-63) 
persediaan barang konsumsi melimpahruah. di kawasan maju. Penduduk dunia diperkirakan lebih dari 10 hingga 14 miliar 3/4-nya tinggal di kawasan terbelakang dengan penununan ekonomi domestik negara dkawasan tersebut (Kennedy, 1995, hlm 29-31; 302-303).

Pertumbuhan ekonomi global 400 $\%$ akhir abad ke 20 berkat teknologi, hanya dinikmati negara maju. Sementara seorang penduduk kawasan miskin hidup dengan kurang 300 dolar pertahun, kawasan tersebut masih harus membayar hutang luar negeri yang membengkak 400 $\%$ dengan sumber daya manusia rentan mental dan pisik.

Tahun 60-an, $31 \%$ penduduk dunia kawasan maju mengonsumsi $87 \%$ energi dunia, dekade terakhir abad ini, $23 \%$ penduduk dunia mengonsumsi $67 \%$ energi dunia (Schumacher, Kecil, 1985. hlm 24-25). Pada saat yang sama, seorang penduduk negara teknologi seperti Swiss, hidup dengan 40 ribu dolar pertahun atau 100 kali lipat penduduk negara termiskin (Kennedy, 1995, hlm 66-69; 299-306). Seperempat abad lalu ketimpangan kayamiskin demikian masih berbanding 20:1 (Haq, 1983, him 53, 143).

Hingga akhir, abad ke 21 , ketimpangan pertumbuhan penduduk dunia (3:1), kelimpahruahan energi (1:21), bahkan pendapatan perpakita pertahun (1:100). Sementara kawasan berkembang masih harus membayar hutang dengan kondisi fisik-mental yang rentan ((Keninedy, 1995, hlm 29-69; 299-303; (Schumacher, Kecil, 1985, him 24-25). Seperempat abad lalu ketimpangan pendapatan kaya-miskin masih berbanding 20:1 (Haq, 1983, him 53, 143).

Sementara seorang artis menghabiskan sekitar 1 miliar untuk pesta perkawinan, beberapa kantor pemda berlebihan membangun fasilitas birokrasi (rumah dinas, kolam renang, kendaraan). Sekali biaya makan orang kaya, cukup untuk ratusan rakyat miskin dan betapa sulitnya orang bantaran ciliwung kembali ke desa tanpa tanah garapan. Sementara mereka "terusir", beberapa gelintir orang membangun garden city ${ }^{6}$ dengan fasilitas modern serba berlebihan di pinggiran kota yang cukup untuk tinggal ribuan orang.

Dalam keadaan demikian, pemberdayaan ekonomi rakyat sering menjadi legitimasi elit politik dan ekonomi seperti kasus tebu rakyat yang justru membuat petani merugi. Pendapatan sekitar 60 ribu perbulan penduduk kawasan berkembang, masih tergolong tinggi bagi sebagian besar penduduk (27 juta) yang terperangkap kemiskinan di Indonesia. Mereka pun masih harus membayar biaya hidup lebih mahal karena tenaga kerja murah dan waktu hidup tidak efektif, di tengah pertumbuhan ekonomi nasional yang cukup menggembirakan sekitar 800 US dolar (Kompas, 26/10/95 hlm 13).

Dalam situasi itu, agenda Pembangunan Nasional, adalah perhatian serius $56,63 \%$ penduduk usia 10 th ke atas yang tak tamat SD $(88,5$ juta lebih), $60 \%$ (80 juta) petani dan $70 \%$ penduduk desa dengan fasilitas hidup pas-pasan, rentan dan serba kekurangan. Dekade pertama tahun 2000, eksodus 20 juta pemuda pedesaan ke kota di antara 210 juta penduduk memerlukan kearifan sosial dan kemanusiaan lebih dari sekedar kebijakan jangka pendek.

Sebagian pemuda desa yang ke kota di atas untuk mencari pekerjaan dengan bekal pendidikan rendah, dan lainnya untuk studi lanjut. Jumlah mereka akan merupakan penambahan beban baru kawasan kota (BPS, Ciri Pemeluk, 1994; Proyeksi, 1994). Sementara "pengusiran" atas mereka yang terus mendesak wilayah pinggiran kota, bukanlah penyelesaian,

6) Lihat uraian lobih lanjut Kuntowijoyo"Muhammadiyah sebagai Gerakan Kebudayaan" dalam Ade Ma'rut WS \& Zulfan Heri, Muhammadiyah Dan Pemberdayaan Rakyat, Pustaka Pelajar, 1995, Yogyakarta. 
tapi menambah masalah yang dapat menimbulkan keresahan dan resiko sosial yang lebih rumit.

Tanpa kritik filosofis, modernitas dan keagamaan, manusia akan terus menjadi kurban. Sikap eksklusif modemitas akan menempatkan manusia kelas pinggiran Iptek ciptaannya (Schumacher, Kecil, 1985, him 102). Sementara sikap eksklusif keagamaan menciptakan ambiguitas sosial-budaya komunitas agama. Karena itu, keterbukaan logika modern sekaligus historisitas keagamaan, merupakan basis kemanusiaan pengembangan strategi peran agama ${ }^{7}$

\section{SIntesis Realitas dalam Moral Kenabian ${ }^{8}$}

Berbagai persoalan yang paradok di atas bersumber pada kegagalan manusia membuat sintesis religiositas modern. Iptek gagal menangkap makna realitas yang tampil dalam keragaman fenomen dan keagamaan gagal menangkap pesan kenabian, sehingga menjadi suci dan saleh diartikan menghindar dari pergumulan dinamis sejarah. "Pertempuran" agama dan Iptek belum berakhir, sintesis keduanya disikapi penuh curiga kedua pihak. Modernisme secara sombong mengabaikan realitas metafisis, dan membiarkan diri terjebak dalam struktur ketidakadilan yang diciptakannya sendiri (lihat Schumacher, Kecil, 1985).

Sejarah merupakan cerita "penderitaan" manusia (Berger, 1982), dan pesan kerahmatan risalah para nabi, gagal ditangkap sejarah. Negara dan orangorang kaya terus mengembangkan kemampuan membuat energi lebih murah dengan daya lebih tinggi, bahkan bersama pasar tunggal menahan laju inflasi. Sementara mereka yang lemah terus terpunuk dalam penderitaan tanpa tangan kuat yang bersedia memberi kesempatan mereka untuk bangkit ${ }^{\text {}}$.

Naisbitt (1990) memihak negara teknologi, namun mengabaikan hak hidup
1 miliar manusia yang setiap hari berjuang menahan lapar untuk bertahan hidup (Korten, 1993, hlm 20-25). Paul Kennedy (1995) menjelaskan selingkuh peradaban modern dengan ketidakadilan akibat malapraktek teknologi. Risiko sosial ketidakadilan terlihat dalam fenomena kekerasan metropolitan Jakarta, sebelum pasar bebas merasuk dalam struktur budaya. Pembunuhan Perdana Menteri Yitzak Rabin atas nama Tuhan menunjukkan cermin kebangkrutan modernitas dan kegagalan keagamaan.

Isu HAM dan demokratisasi terperangkap logika modern yang sektarianis, sehingga rasialisme Amerika sulit dipecahkan (Goldscheider, 1985, hlm 361-388). Sementara Partai Republik merasa sah merebut kemenangan lewat "martir" anggaran Demokrat. Clinton dengan resiko ratusan ribu penganggur. Bioteknologi bersama teknokultur membuat manusia robot tanpa jiwa dan perasaan (Kennedy, 1995). SDM dikembangkan sebagai konspirasi (selingkuh) kecerdasan dan teknologi menguasai seluruh SDA bagi kepentingan dirinya bagaikan ramses. Moralitas kapitalis (al taka-tsur), menjadikan kejujuran berarti suap dan korupsi yang dipandang sebagai alat produksi dan politik (Naisbitt, Paradox, 1994).

7) Tinjauan kritis terhadap modemitas lihat Schumacher dalam dua bukunya Kecil Itu Indah. 1985, LPES, Jakarta; dan Keluar Dari Kemelut;Sobuah Peta Pemikiran Baru, 1981, .LP3ES, Jakarta. Lihat juga kritik Jurgen Habermas dan Kritik Idelogi dalam tulisan Hardiman yang diterbitkan Kanisius, Yogyakarta.

8) Lihat "kebijaksanaan kenabian" tulisan Kuntowijoyo "Kebudayaan, Masyarakat industri Lanjut, dan Dakwah" dalam Materi Muktamar Muhammadiyah ke- 43, PP Muhammadiyah, 1995, him 45-54, Yogyakarta

9) Mengenai krișis dan ketimpangan penggunaan energi hasil eksploitasi alam, lihat lanjut analisis E.F. Scumacher dalam Kecil Itu Indah, 1985, LP3ES, Jakarrta. 
Etika kemanusiaan agaknya berlawan arah dengan modernitas sekaligus gagal ditangkap sebagai pesan dakwah kenabian. Al Qur'an secara jelas menyatakan bahwa sejarah selalu menempatkan mereka yang terbaik megatasi konflik kepentingan; mengatasi bukan menghindari (lihat surat AI Baqarah 214; Al An'aam 57).

Reorientasi modernitas dan pembangunan serta keagamaan berwajah manusia, sudah merupakan kehanusan sejarah - (lihat perspektif ekonomi-politik baru dalam Seminar FE UGM; Kompas, 23-26/10/95). Penempatan manusia bukan sekedar ketubuhan tetapi sekaligus dalam posisi metafisis (Schumacher, Keluar, 1981) merupakan pesan kenabian industrial, sehingga bebas dari konflik kepentingan ${ }^{10}$.

Transendensi bendawi atas struktur. metafisis, adalah pengendali kerakusan yang membuat manusia bersedia berlaku adil. Kenabian, adalah visi kritis materialisasi kemanusiaan dan sejarah sebagai basis kepasrahan pada kebenaran dan keadilan. Di dalamnya terakumulasi kepentingan manusia di luar batas keluarga, etnik, dan primordialitas politik, sehingga moral kenabian sebagai paradigma sosial dan rancang-bangun pembangunan.

Moral kenabian berarti pemberdayaan manusia melampaui modernitas dinamika historis kebendaan, bebas konspirasi politis kaum elit. Pengembangan kawasan industri tidak sekedar dalam tata hubungan alat produksi, tapi dalam kerangka kemasyarakatan alamiah. Disinilah moral kenabian mengatasi individualitas dalam tataran transendental, integrasi seluruh kepentingan personal dalam kepentingan transenden. Kepemilikan harta dan kekuasaan tidak eksklusif tetapi bebas dari pertentangan individu sebagai kepentingan kolektif karena berada dalam kepentingan kenabian.
Ketidakadilan dunia modern menurut Schumacher (Kecil, 1985) akibat hasil produksi menjadi milik mutlak pribadi. Sementara moral kenabian menempatkan kekuasaan dan kepemilikan harta sebagai amanah dimana atas nama Tuhan semua orang berhak memperoleh manfaat (Husaini,. 1983, hlm 294-302). Kesejahteraan ekonomi bukan ukuran pembangunan tapi alat bagi kesejahteraan totalitas kemanusiaan. Distribusi alat produksi diatur menurut perwalian ekonomi, yang tak berdaya tetap memiliki peluang hidup sejahtera. Berger (1982) menyebutnya "biaya manusiawi", sehingga keuntungan bukan diperoleh dari ketimpangan distribusi, tapi hasil bersih pemerataan produksi secara adil (Husaini, 1993, hlm 299).

Kemajuan atau keberhasilan hanya dapat dicapai dalam keterlibatan manusia universal, sehingga keadilan distribusi bukan pengeluaran, tapi bagian dari keuntungan perusahaan. Ekonomi tidak sekedar hubungan produksi, tapi fungsi realitas metafisis amal shaleh, sehingga harta pribadi ditransendensi memiliki hak sosial dalam perspektif iman (tauhid). Kalimat thayyibah menjadi media optimisme yang lemah, dan fungsi sosial berkeadilan sebagai jalan mencapai martabat spiritual bagi yang kuat". Persoalannya adalah bahwa tradisi keagamaan akan berperan memberi pencerahan peradaban modern industrial jika dikembangkan dalam fungsi dinamika sejarah kemanusiaan khususnya mengenai pengembgangan aksi bagi keadilan tersebut.

10) Lihat sintesa realitas fisik dan metafisis (rohaniah spiritual) sebagai jalan tengah dan tiga tingkat kesadaran sebagaimana penjelasan dalam catatan kaki yang telah disebutkan di atas.

11) Lihat kasus sahabat Rasul yang mengadukan kemiskinannya serta peluang keadilen memperoleh ganjaran tindakan dalam Hadits Arbain An Nawawi. 
Risiko sosial yang disadari mengenai akibat ketidakadilan menjadi "pemaksa" rasional bagi tindakan ekonomi dan politik. Sejarah memberi pelajaran mengenai hubungan modernitas dengan revolusi. Revolusi industri (ekonomi) Inggris dan revolusi politik Perancis, melahirkan dua revolusi simultan lanjut yaitu ekonomi global dalam revolusi telekomunikasi (Naisbitt, 1994, Global Paradox). Lahirlah mega-budaya abad informasi, dan pasar tunggal dalam perdagangan bebas, namun tetap menyisakan persoalan mengenai keadilan dan pemartabatan manusia.

Dua revolusi terakhir di atas muncul bersamaan dengan revolusi filosofis renaisance dan aufklarung menjadi dasar paradigmatik modernisasi dan developmentalisme atau pembangunan. Modernisme melahirkan ketimpangan dan ketidakadilan yang memberi inspirasi proyek humanisasi atau penyadaran kembali atas dunia dan dirinya sendiri. Akumulasi risiko sosial potensial terhadap "revolusi" disadari sebagai harapan yang secara rasional (lihat harapan rasional Robert Lucas; Usman, Kompas, 17/10/95, hIm 13) menjadi dasar pilihan tindakan pelaku ekonomi dan politik.

Peran Agama dalam Kemanusian Industrlal ${ }^{12}$

Sudah lebih 2500 tahun manusia mencari dirinya, namun belum juga tuntas. Dunia dan manusia tetap merupakan misteri penuh rahasia. Spekulasi ilmiah sampai teori ledakan super nova yang menjelaskan asal-muasal alam tempat manusia hidup. Peradaban mutakhir sedang memburu teknologi mesin waktu yang mampu menggerakkan manusia keluar dari jebakan ruang dan gravitasi (Hawking, 1994; 1995) dan bertandang ke zaman Adam minta pertanggungjawaban. Pada saat demikian muncul pertanyaan mengenai tersisa tidaknya rahasia Tuhan dengan segala risiko logis yang menyertai. Pertanyaan teologis yang mungkin dianggap melanggar doktrin keagamaan demikian, tak mungkin dihindari untuk dijelaskan.

Sementara hidup tetap tak bisa dihentikan dan sejarah terus berlangsung, manusia memaksa diri membangun berdasar pengetahuan yang belum dan tak pernah selesai. Modernisme justru merasa pasti atas kebenaran dan kebaikan dengan mengabaikan hal-hal mistis dan spiritual yang tak pernah dapat ditangkap dalam ukuran baku.

Secara gegabah dunia modern menepiskan bidang metafisis ketuhanan sebagai bidang tak penting, walaupun gagal membuktikan tidak adanya bidang metafisis. Peradaban modern berada dalam ambiguitas dihotomi realitas tersebut. Konsep integrasi dimensi sakral transenden dengan imanen sekuler, segera berhadapan dengan logika modern yang tidak terbiasa memasuki wilayah yang tidak seluruhnya logis, empiris dan obyektifis tersebut. Karena itu akan bijak jika gagasan tersebut didialogkan dengan logika peradaban modern industrial yang sekarang mamasuki aras global.

Gugatan Nietschze kepada Tuhan, tampaknya merupakan pertanyaan perenial ketika selalu muncul dalam sejarah nabi-nabi. Modernisme sebagai akar berbagai teori pembangunan merupakan proklamsi peradilan Tuhan, ketika renaisance dan aufklarung meminggirkan agama di luar wilayah praksis kehidupan manusia.

Fenomena kesejarahan alam dan manusia mencerminkan rahasia seluas cakrawala semesta dan keragaman manusia. Justru ke-misterius-an demikian mendorong penelitian dan karya ifmiah yang terus mengalir bagaikan sungai tanpa muara. Inilah ciri khas manusiawi yang

12) Uraian penulis mengenai masalah ini pernah dimuat dalam harian Kedualatan rakyat of bawah judul "Gagasan tauhid Sosial dan Agenda Publik Keagamaan, 23 Nopember 1995, hlm 4. 
unik sekaligus universal, dimana hidup dan sejarah berlangsung dalam panduan pertanyaan tersebut. Kebajikan insani justru terletak pada kesadaran mengenai misteri yang menunjukkan batas-batas kemampuan manusia dan melahirkan wisdom atau hikmah. Inilah ilmu sejati yaing diburu filsuf, ilmuwan dan kaum sufi. Sayangnya, sering tersembunyi dalam wilayah paling dekat manusia, sehingga sulit disadari kehadirannya.

Modernisme justru merasa pasti atas kebenaran dan kebaikan dengan mengabaikan hal-hal mistis dan spiritual yang tak pernah dapat ditangkap dalam ukuran baku. Secara gegabah dunia modern menepiskan bidang metafisis ketuhanan (Schumacher, Keluar, 1981) sebagai bidang tak penting, walaupun tak pernah berhasil membuktikan tidak adanya bidang metafisis. Peradaban modern kemudian berada dalam ambiguitas dihotomi realitas tersebut.

Futuris mulai meramalkan mengenai kebangkitan agama yang tanpa atribut institusi menjadi topeng relativisme spiritual modern. Sementara antusiame agamawan akan berhadapan dengan agama ilmuwan gagasan Auguste Comte dalam wajah lebih global dan industrial. Namun demikian kematian Yitzak Rabin sebagai martir perdamaian akan pemicu keraguan model keagamaan konvensional yang sebaliknya dituduh sebagai biang kekerasan fundamentalisme. Agawaman kembali akan menghadapi serangan ilmuwan seperti prolog renaisance dan afuklanung awal abad ke 19. Elit intelektual agama pun dituduh sebagai pemicu politik aliran yang sektarianistis.

\section{Pemeranan}

keagamaan memerlukan kerangka operasional yang tidak sekedar mampu berdialog dengan modernitas industrial, tapi mengatasi berbagai kesulitan - modernitas mengembangkan proyek kemanusiaan dan keadilan: Tidak ada pilihan kecuali kajian kritis seluruh khasanah Islam, sehingga agama menjadi wilayah publik, dan dokrtrin tekstual terus berdialog dengan konteks sejarah yang dinamis. Keberagamaan menjadi cara manusia melakukan transendensi keluar dari konflik kepentingan individual metarialistis, sehingga kedamaian dan keadilan kesejahteraan manusia menjadi mungkin.

Kebangkitan agama menimbulkan harapan palsu mengenai peran agama tradisional. Sementara agama peradaban industrial terbatas penghargaan dimensi spiritual berbeda dari tradisi agama konvensional sebagai pembebasan manusia dari struktur baku mekanisme industrial. Hal yang tidak biasa di luar rutinitas ditangkap sebagai dimensi ruhaniah spiritual, mencari kepuasan rohani dengan perilaku yang bebas dari jadwal harian. Seperti juga mulai marak di berbagai kota besar di Indonesia, orangorang kaya yang berkelimpah-ruahan benda materiel dari sandang, papan, pangan dan kendaraan, seluruh waktu hariannya habis untuk berhubungan dengan benda-benda berlimpah tersebut. Mereka mulai merasakan sesuatu bagian hidup yang hilang dan mulai tertarik kegiatan hidup yang telah lama ditinggal dan dilupakan, sehingga kembali melantunkan do'a dan upacara ritual dengan kesediaan membayar cukup mahal.

Bersamaan itu masyarakat Indonesia benar-benar akan berbeda ketika berada di tengah pasar bebas dengan segala keuntungan dan resiko sosial yang harus di bayar. Perlu dikembangkan strategi keagamaan yang tidak hanya berorientasi pemecahan tapi pemihakan keadilan sosial, politik terutama ekonomi. Pemikiran sufistik dapat dipertimbangkan dengan modifikasi teknologis, sehingga tidak justru menciptakan sekedar budaya tandingan yang kekirian atau kekananan atas modernitas melainkan memandu pemikiran ke arah jalan tengah perimbangan konflik kepentingan dan keadilan. Proyek ini perlu pemikiran yang mendalam bersisi ganda; sebagai kritik 
khasanah Islam dan sekaligus peradaban modern, bersamaan membangun konstruk pikiran melampauai pertentangan historis tradisi Islam dan peradaban modem industrial.

Dengan demikian dapat dikembangkan suatu konsep mengenai kualitas dan derajat soșial yang bukan semata jumlah penguasaan atas barang dan fasilitas sosial tapi kemampuan memanfaatkan keduanya bagi kepentingan bersama. Penguasaan sejumlah harta-benda tidak hanya dipandang sebagai hak milik personal, tapi sekaligus berfungsi sosial. Keadilan ditribusi produksi barang dan jasa melalui berbagai kegiatan sosial budaya bukanlah bagian dari pengeluaran, melainkan ditempatkan dan dihargai sebagai bagian dari keuntungan produktif.

. Selanjutnya, sejarah merupakan bukti otentik bahwa kemenangan tanpa keadilan melahirkan pergolakan dan revolusi yang harus dibayar yang melumatkan seluruh karya manusia. Karena itu tidak ada kemenangan melainkan kemenangan manusia atas dirinya sendiri bagi hidup bersama yang lebih langgeng dan surgawi. Iptek tidak dikembangkan untuk membuat manusia tak berdaya daripada yang lain akibat runtuhnya sistem produksi tradisional, tapi agar setiap orang mampu memberdayakan diri bagi keberdayaan orang lain.

Keberhasilan pembangunan tidak hanya diukur dari prestasi ekonomis, politik bahkan budaya jangka pendek, tapi ditelakkan dalam kalkulasi jangka panjang dan global. Hanya dari pendekatan sejarah yang terbuka dan optimis seseorang menjadi lebih peduli nasib tetangga, sahabat dan orang lain. Etika pembangunan bukan hanya moral personal, tapi konsekuensi sejärah dan globalisasi planet bumi. Kemenangan dan sukses hanya dapat dicapai jika oráng lain terlibat bukan kemenangan, palsu berjangka pendek.
Agenda besar keagamaan bagi pembangunan bersumber. gagasan pemberdayaan makro ekonomi-politik modernisasi beserta teknologi dan negara bagi pemberdayaan rakyat. Pemeranan agama dilakukan melalui Iptek dan sebaliknya Iptek beroperasi dalam perspektif keagamaan sehingga memperoleh visi kemanusiaan. Karena itu, di șamping dikembangkan proyek teoritis pendekatan kritis terhadap modernisme dan tradisi keagamaan, dikembangkan aksi keagamaan bagi pemberdayaan kemanusiaan.

\section{Daftar Pustaka}

Bakker, A., 1992, Ontologi Metafisika Umum; Filsafat Pengada dan Dasar-Dasar.Kenyataan, Kanisius, Yogyakarta.

Basyir, A., 1993, Refleksi Atas Persoalan Keislaman; Seputar Filsafat, Hukum, Politik dan Ekonomi, Mizan, Jakarta.

Belling dan Totten, 1985, Modernisasi Masalah Model Pembangunan, Y.IS \& Rajawali, Jakarta.

Berger, P.L., 1995, Religion and Modernity, Jakarta Conference, Jakarta.

Berger, P.L. \& Hansfried Kellner, 1981, Sosiologi Ditafsirkan Kembali; Esei tentang Metode dan Bidang Kerja, LP3ES, Jakarta.

Belling Berger, P.L., 1982, Piramida Kurban Manusia; Etika Politik Dan

- Perubahan Sosial, LP3ES, Jakarta.

BPS, 1994, Beberapa Ciri Pemeluk Agama Di Indonesia 1990, BPS, Jakarta.

BPS, 1992, Penduduk Indonesia Hasil Sensus 1990, Seri S2, BPS, BPSJakarta.

BPS, 1994, Proyeksi Penduduk Indonesia Per Kabupaten/ Kotamadya 19902000, Jakarta.

BPS, 1984, Beberapa Ciri Pemeluk Agama di Indonesia 1980, BPS, Jakarta.

Brant, W, 1980, Utara-Selatan, Leppenas, Jakarta. 
Coward, Harold, 1989, Pluralisme; Tantangan bagi Agama-Agama, Kanisius, Yogyakarta.

Goldscheider, C., 1985, Populasi, Modernisasi, dan Struktur Sosial, Rajawali, Jakarta.

Hadiwijono, H., 1980, Sari Sejarah Filsafat Barat I \& II, Kanisius, Yogyakarta.

Haq, M., 1983, Tirai Kemiskinan; Tantangan-tantangan Untuk Dunia Ketiga, Yayasan Obor Indonesia, Jakarta.

Hawking, S., 1994, Riwayat Sang Kala; Dari Dentuman Besar hingga Lubang Hitam, Pustaka Utama Grafiti, Jakarta. 1995, Black Holes And Baby Universes; Lubang Hitam Dan Jagat Bayi; dan Esei-esei Lain, Gramedia, Jakarta.

Hardiman, F.B., 1990, Kritik ldeologi, Kanisius, Yogyakarta. 1 1993, Menuju Masyarakat Komunikatif; IImu, Masyarakat, Politik \& Postmodernisme Menunt Jurgen Habermas, Kanisius, Yogyakarta.

Huntington, S.P., 1993, Benturan. Kebudayaan?, Al Jami'ah No. 53 Th 1993, Jurnal Ilmu

Pengetahuan Agama Islam, IAIN Sunan Kalijaga, Yogyakarta.

Huntington, S.P., 1995, Gelombang Demokratisasi Ketiga, Pustaka Utama Grafiti, Jakarta.

Izutsu, T., 1994, Konsep Kepercayaan dalam Teologi Islam; Analisis Semantik Iman dan Islam, Tiara Wacana, Yogyakarta.

Izutsu, T., 1993, Konsep-Konsep Etika Religius dalam Qur'an, Tiara Wacana, Yogyakarta.

Kattsoff, L.O., 1986, Pengantar Filsafat, Tiara Wacana, Yogyakarta.

Kennedy, P., 1995, Menyiapkan Diri Menghadapi Abad Ke-21, Yayasan Obor Indonesia, Jakarta.

Kuhn, T.S., 1989, Peran Paradigma Dalam Revolusi Sains, Remadja Karya,
Bandung.

Kuntowijoyo, 1995, "Muhammadiyah sebagai Gerakan Kebudayaan" dalam Ma'ruf WS, A. \&

Zulfan Heri, Muhammadiyah Dan Pemberdayaan Rakyat, Pustaka Pelajar, Yogyakarta.

1995, "Kebudayaan, Masyarakat Industri Lanjut, Dan Dakwah" dalam PP Muhammadiyah, Materi Muktamar Muhammadiyah ke-43, Yogyakarta.

Latif, Y, \& Subandy Ibrahim, 1994, "Kekerasan" Spiritual Dalam Masyarakat Pasca-Modern" dalam Ulumul Qur'an No. 3, VotV Th 1994, hlm 72-83, Jakarta.

Leahy, L., 1984, Manusia Sebuah Misteri, Gramedia, Jakarta.

Long, N., 1987, Sosiologi Pembangunan Pedesaan, Bina Aksara, Jakarta.

Madjid, N., 1995, Islam, Agama Kemanusiaan, Paramadina, Jakarta.

Magnis, F.v., 1979, Etika Umum, Kanisius, Yogyakarta.

Mulkhan, A.M., 1994, Paradigma Intelektual Muslim; Pengantar Filsafat Pendidikan Is/am dan Dakwah, cet 2, Sipress, Yogyakarta. 1995, Teologi. Kebudayaan dan Demokrasi Modernitas, Pustaka Pelajar, Yogyakarta.

1995, "Islam dan Kebudayaan Kritis" dalam Kompas, 10 Oktober 1995, hlm 4-5.

Mulkhan, A.M., 1995, "Gagasan Tauhid Sosial dan Agenda Publik Keagamaan", Kedaulatan Rakyat, 23 Nopember 1995, hlm 4.

Mutahhari, M., 1986, Masyarakat Dan Sejarah; Kritik Islam atas Marxisme dan Teori Lainnya, Mizan, Bandung.

Nabi, M.b., 1994, Membangun Dunia Baru Islam, Mizan, Jakarta.

Naisbitt, J., 1994, Global Paradox, Binarupa Aksara, Jakarta.

Naisbitt J., \& Patricia Aburdene, 1990, Sepuluh Arah Baru untuk Tahun 
1990-an; Megatrends 2000, Binarupa Aksara, Jakarta.

Sardar, Z., 1992, Rekayasa Masa Depan Peradaban Muslim, Mizan, Bandung.

Sardar, Z., 1989, Sains, Teknologi Dan Pembangunan Di Dunia Islam. Pustaka, Bandung.

Schumacher, E.F., 1985, Kecil ltu Indah, LP3ES, Jakarta. 1981, Keluar Dari Kemeluit, LP3ES, Jakarta.

Soedjatmoko (dkk), 1986, Masalah Sosial Budaya Tahun 2000, Tiara Wacana, Yogyakarta.

Syariati, Ali, 1990, Ideologi Kaum Intelektual; Suatu Warisan Islam, Mizan, Jakarta.
Usman; W., 1995, "Mengapa "Harapan Rasional' Penting ?", Kompas, 17 Oktober 1995, him 13.

Ward, B. \& Rene Dubos, 1974, Hanya Satu Bumi, Gramedia, Jakarta.

Wibisono, K, 1983, Arti Perkembangan Menurut Filsafat Positivisme Auguste Comte, Gadjah Mada University Press, Yogyakarta.

Zen, M.T. (ed), 1981, Sains, Teknologi Dan Hari Depan Manusia, Gramedia, Jakarta.

Kompas, 28-31 Agustus 1995.

Kompas, 1995, Laporan Seminar FE-UGM tentang Strategi Pembangunan Ekonomi dan Bisnis, 23-26 Oktober 1995.

Prisma, No. 6, Th. XIII, 1994. 